N.M. Dolaberidze, V.G. Tsitsishvili, N.A. Mirdzveli, N.O. Nijaradze

\title{
SYNTHESIS OF LTA TYPE ZEOLITES FROM GEORGIAN CLINOPTILOLITE
}

\author{
Petre Melikishvili Institute of Physical and Organic Chemistry of Ivane Javakhishvili Tbilisi State University \\ 31 Politkovskaia Str., Tbilisi,0186, Georgia,E-mail:n_dolaberidze@yahoo.com
}

Generally, the microporous structure of synthetic zeolite is affected by the nature of used reactants and their pretreatments, as well as by composition of the reaction mixture. Our recent investigation of hydrothermal transformation of natural Georgian clinoptilolite demonstrated possibility of preparation of zeolites with high silicon content (mordenite-like materials) without organic template, directly from aged gels having suitable chemical composition and prepared by acid treatment of raw material. The aim of present work was preparation of zeolites with high aluminium content on the same basis without organic templates. The study tested possibility of synthesis of the LTA type zeolites in following steps: treatment of the natural clinoptilolite $\left(\left(\mathrm{Na}_{3.3} \mathrm{~K}_{1.15} \mathrm{Ca}_{0.75} \mathrm{Mg}_{0.25}\left[\mathrm{Me}_{0.55}\right)\left(\mathrm{Al}_{7.0} \mathrm{Si}_{29.3} \mathrm{O}_{72}\right) \cdot 22.5 \mathrm{H}_{2} \mathrm{O}\right.\right.$, where $\mathrm{Me}=\mathrm{Cu}, \mathrm{Zn}, \mathrm{Ba}$, etc. $)$ in $\mathrm{HCl}$ water solution; gel preparation by suspension in $\mathrm{NaOH}$ solution; its hydrothermal crystallization to the sodalite structure (SOD) with $\mathrm{Si} / \mathrm{Al}=1$, and then re-crystallization of the sodalite into the NaA zeolite (LTA). Chemical elemental analyses confirm a good accordance with the UPAC SOD and LTA chemical formulas for prepared materials having nearly monocationic composition ( $N a-78 \%$ SOD and $89 \%$ LTA). In XRD patterns there are no additional peaks from zeolitic or other impurities, prepared materials have high crystallinity, their FTIR spectra are typical for SOD and LTA structures, developed zeolitic crystal microporous structure is confirmed by comparatively high averaged value of water adsorption capacity $\left(0.08 \mathrm{~cm}^{3} / \mathrm{g}\right.$ for SOD, and of $0.24 \mathrm{~cm}^{3} / \mathrm{g}$ for LTA at p/p $\left.p_{S}=0.4\right)$. SEM images show uniform LTA micrometric crystallites (average diameter $4 \mu \mathrm{m}$ ) with fairly narrow distribution of sizes produced by lasting (> 10 h) low temperature crystallization, as well as nanoscale spherical zeolites (0.2 $\mu \mathrm{m})$ and fibrous aggregates $(0.08 \mu \mathrm{m})$ produced at low temperature, that can be used for preparation of composite and hierarchical structures for various catalytic and adsorptive applications.

Keywords: zeolite A, Georgian clinoptilolite, sodalite, hydrothermal synthesis

\section{INTRODUCTION}

At the end of the $20^{\text {th }}$ century, the United States Environmental Protection Agency published a technical bulletin [1], in which it made recommendations on the use of different systems to adsorb volatile organic compounds (VOC) and other pollutants from relatively dilute concentrations in air (from tens to thousands of parts per million by volume) to control emissions.

It was noted that carbon and polymers have a linear adsorption isotherm relative to vapor pressure, and this linearity makes either carbon or polymers the better adsorbent when the vapor pressure (or concentration) is higher, while zeolite has a very non-linear adsorption isotherm relative to vapor pressure for the molecules it has an affinity to, and this makes zeolite the better adsorbent when the vapor pressure (or concentration) is lower. According to the authors of the report, this property allows carbon or polymer adsorbent in a "sacrifial" (or first) bed followed in the air flow by a suitable zeolite in a "polishing" bed to produce the lowest vapor pressure of VOC in the outflow.

The synthetic zeolites are used commercially more often than natural zeolites due to the purity of crystalline products and the uniformity of particle sizes. The sources for early synthesized zeolites were standard chemical reagents, but today attention is paid to synthesis from low cost materials, such as clay minerals, natural zeolites, coal and other incineration ashes, etc. The type of the zeolite is affected by the nature of reactants and their pretreatments, as well as by composition of the reaction mixture ( $\mathrm{Si} / \mathrm{Al}$ ratio, $\mathrm{OH}-$, inorganic cations), while the sizes of products and their morphology are affected by conditions of the hydrothermal process (temperature, reaction time, $\mathrm{pH}$ of mixture). Modern trends in the synthesis of "bulk" and "hollow" zeolites have been considered in review [2].

The aim of present work was to demonstrate possibilities to carry out synthesis of zeolitic 
materials with necessary system of pores and channels, as well as with suitable morphology of crystallites reproducing mesoporous structure of natural zeolites, having a number of useful properties, including possibility to bound macromolecules and even microorganisms.

\section{EXPERIMENTAL}

Preparation of synthetic zeolite material was carried out using Georgian natural clinoptiloliteheulandite-containing rock from the Rkoni plot of Tedzami deposit [3] having chemical composition

$\left(\mathrm{Na}_{3.3} \mathrm{~K}_{1.15} \mathrm{Ca}_{0.75} \mathrm{Mg}_{0.25}[\mathrm{Me}]_{0.55}\right)\left(\mathrm{Al}_{7.0} \mathrm{Si}_{29.3} \mathrm{O}_{72}\right) 22.5 \mathrm{H}_{2} \mathrm{O}$, where $\mathrm{Me}=\mathrm{Cu}, \mathrm{Zn}$ (EDS registered), $\mathrm{Ba}$ and other metals. According to X-ray diffraction pattern, it belongs to the $\mathrm{Na}, \mathrm{K}$-form of $\mathrm{HEU}$ (UPAC chemical formula $\left|\mathrm{Ca}_{4}\left(\mathrm{H}_{2} \mathrm{O}\right)_{24}\right|$ $\left[\mathrm{Al}_{8} \mathrm{Si}_{28} \mathrm{O}_{72}\right]$ ) type natural zeolites and is characterized by IR spectrum, water adsorption capacity and thermal analysis data.

Processing of raw in target material includes following steps:

Treatment of raw material \& preparation of suspension. Natural zeolite powder was treated at room temperature by $20 \% \mathrm{HCl}$ aqueous solution under stirring, washed by water before the complete disappearance of $\mathrm{Cl}^{-}$ions, and dried in oven at $100-105^{\circ} \mathrm{C}$; water suspension of treated material was prepared with the solid to liquid ratio of 1:3.

Gel formation. Prepared suspension was treated at room temperature by $10 \% \mathrm{NaOH}$ aqueous solution, solid to liquid ratio of $1: 6$, gel homogenization takes $30 \mathrm{~min}$, details are given in [4]. General characteristics of target material are in strong dependence on the chemical composition $\left(\mathrm{kNa}_{2} \mathrm{O}: \mathrm{mSiO}_{2}: \mathrm{Al}_{2} \mathrm{O}_{3}: \mathrm{nH}_{2} \mathrm{O}\right)$ of gel prepared for aging and crystallization: the $\mathrm{SiO}_{2} / \mathrm{Al}_{2} \mathrm{O}_{3}$ ratio determines the type of microporous structure to be produced, and application of sodium hydroxide gives a possibility to prepare nearly monocationic sodium forms; water content generally is rather high to ensure suitable physical properties (viscosity, etc.) for crystallization process, but water molecules are compulsory units to built zeolite structure and play a significant role.

Gel aging. Generally the process of gel aging at room temperature and without application of seed crystals takes several days, details are described in [5].
Crystallization. Crystallization of aged gel was carried out in the Teflon flasks at different temperatures up to $110^{\circ} \mathrm{C}$, duration of the process - up to 90 hours; both temperature and duration affect to crystalline sizes - low temperature prolonged synthesis gives high quality large crystals, high temperature fast crystallization is a way to produce "nanozeolites" and their fibrous aggregates.

Separation and cleaning. Separation of produced crystalline material was carried out by filtration of mother solution, solid material was cleaned by water until $\mathrm{pH} 8.0-8.5$, and dried at $90-100{ }^{\circ} \mathrm{C}$.

Recently [6] synthesis of mordenite-like materials from gels aged during one week and having chemical composition of $\mathrm{SiO}_{2} / \mathrm{Al}_{2} \mathrm{O}_{3}=9.8$, $\mathrm{Na}_{2} \mathrm{O} / \mathrm{SiO}_{2}=0.08, \quad \mathrm{H}_{2} \mathrm{O} / \mathrm{Na}_{2} \mathrm{O}=250$ has been described, but obtaining of materials with high aluminum content is impossible in such single step.

However, preparation of synthetic zeolitic material of the type A (LTA structure) was carried out by two-stage re-crystallization of the same HEU type natural zeolite firstly to the sodalite (SOD) structure, and then in the target structure: $\mathrm{HEU} \rightarrow \mathrm{SOD} \rightarrow$ LTA, in following steps: preparation and acid treatment of raw material; gel formation and its aging; hydrothermal crystallization; separation of intermediate SOD product, new gel formation without any acid or basic treatment, but including gel aging; crystallization and separation of target product, its washing and drying.

Chemical composition of prepared samples (Table 1) was determined by elemental analyses carried out using a Spectromom 381L plasma spectrometer and a Perkin-Elmer 300 atomic absorption spectrometer, as well as by energy dispersive X-ray (EDS) analysis. X-ray powder diffraction patterns were obtained from a DRON-4 diffractometer, employing the $\mathrm{Cu} K_{\alpha}$ line and scanning at $1^{\circ}$ per minute, FTIR spectra in the wavenumber range $4000-400 \mathrm{~cm}^{-1}$ were recorded on a Perkin-Elmer FTIR spectrometer (version 10.4.2) using the $\mathrm{KBr}$ pellet technique for sample preparation, SEM images were obtained by using a Jeol JSM6510LV scanning electron microscope (parameters are given on figures) equipped with an Oxford Instruments X-Max 20 analyzer for EDS. Water adsorption capacity was measured under static conditions $\left(p / p_{\mathrm{S}}=0.40,20^{\circ} \mathrm{C}\right)$. 
Table 1. Chemical composition of prepared materials compared with IUPAC chemical formula

\begin{tabular}{|c|c|c|}
\hline Sample & Chemical composition & IUPAC chemical formula \\
\hline $\begin{array}{l}\text { Synthetic sodalite } \\
\text { Synthetic } \mathrm{NaA}\end{array}$ & 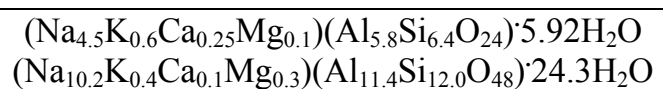 & $\begin{array}{c}\left|\mathrm{Na}_{8} \mathrm{Cl}_{2}\right|\left[\mathrm{Al}_{6} \mathrm{Si}_{6} \mathrm{O}_{24}\right] \text {-SOD } \\
\left|\mathrm{Na}_{12}\left(\mathrm{H}_{2} \mathrm{O}\right)_{27}\right|_{8}\left[\mathrm{Al}_{12} \mathrm{Si}_{12} \mathrm{O}_{48}\right]_{8} \text {-LTA }\end{array}$ \\
\hline
\end{tabular}

\section{RESULTS AND DISCUSSION}

Chemical composition of prepared materials is in a good accordance with corresponding chemical formula with the exception of small "lack" of the $\mathrm{Al}$ atoms in the frame; prepared materials are nearly pure Na-forms (78 \% SOD and $89 \%$ LTA), traces $(<1 \%)$ of $\mathrm{Cu}$ and $\mathrm{Zn}$ have been observed for SOD, other metals are removed in full during first crystallization.

XRD. The framework type of prepared material was testified by X-ray powder diffraction patterns. No additional diffraction peak at $2 \Theta=7.74^{\circ}$ indicating the formation of the BEA type structure or at $2 \Theta=15.8^{\circ}$ indicating the formation of ANA type structure as impurities have been observed after the first crystallization. X-ray powder diffraction pattern of target product was compared (Fig. 1) with calculated one taken from the "Database of Zeolite Structures" of the International Zeolite Association Structure Commission (http://www.iza-structure.org/). Calculated XRD pattern include a large number of low-intensity peaks that are not observed experimentally, so for comparison with recorded pattern only peaks of comparatively high intensity (over $0.09 \mathrm{I}_{\max }$ ) have been taken into consideration (Table 2).

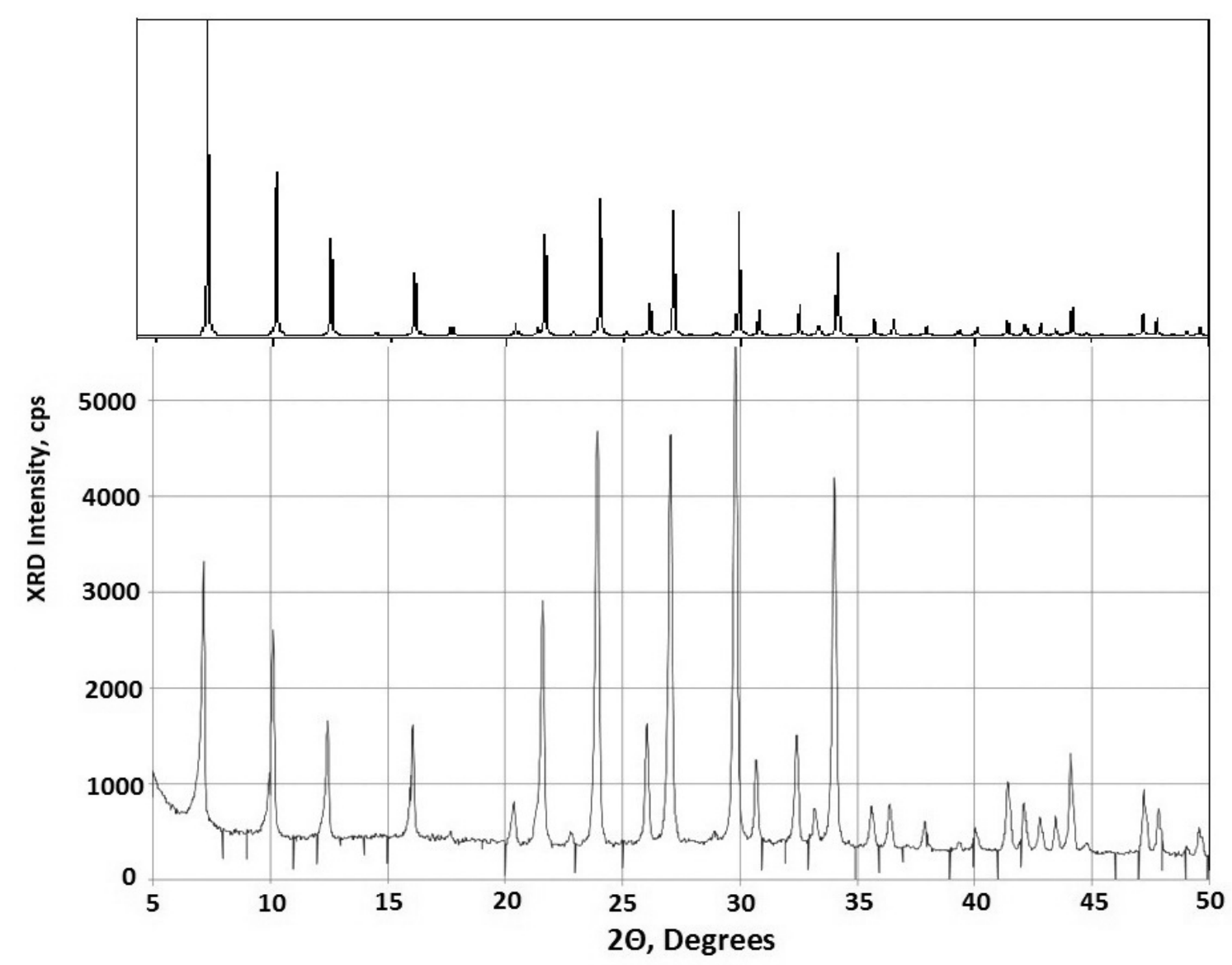

Fig. 1. Experimental XRD pattern compared with LTA calculated XRD pattern 
Table 2. LTA calculated XRD pattern (high intensity peaks) compared with experimental

\begin{tabular}{|c|c|c|c|c|c|}
\hline \multirow{2}{*}{ hkl } & \multicolumn{3}{|c|}{ Calculated } & \multicolumn{2}{|c|}{ Experimental } \\
\hline & $2 \Theta$, degree & $d, \AA$ & $I, \% I_{\max }$ & $2 \Theta$, degree & $I, \% I_{\max }$ \\
\hline 200 & 7.178 & 12.3050 & 100.00 & 7.2 & 100 \\
\hline 220 & 10.158 & 8.7009 & 51.31 & 10.1 & 78 \\
\hline 222 & 12.449 & 7.1043 & 31.82 & 12.4 & 44 \\
\hline 420 & 16.093 & 5.5030 & 20.30 & 16.2 & 42 \\
\hline 600 & \multirow{2}{*}{21.648} & \multirow{2}{*}{4.1017} & 10.62 & 21.1 & 18 \\
\hline 442 & & & 22.78 & 21.8 & 93 \\
\hline 622 & 23.965 & 3.7101 & 44.34 & 24.0 & 1.56 \\
\hline 640 & 26.089 & 3.4128 & 10.11 & 26.0 & 42 \\
\hline 642 & 27.092 & 3.2886 & 41.01 & 26.9 & 1.50 \\
\hline 820 & \multirow{2}{*}{29.915} & \multirow{2}{*}{2.9844} & 19.92 & \multirow{2}{*}{29.9} & \multirow{2}{*}{1.93} \\
\hline 644 & & & 19.70 & & \\
\hline 840 & 32.315 & 2.7515 & 9.34 & 32.9 & 45 \\
\hline 664 & 34.149 & 2.6234 & 27.06 & 34.2 & 1.20 \\
\hline
\end{tabular}

Experimental XRD pattern has the same peculiarities as was mentioned in [7]: high intensity peaks not only at $2 \Theta=7^{\circ}$ and $10^{\circ}$, but at $2 \Theta=24,27,30$, and $34^{\circ}$. With the molar ratio $\mathrm{Si} / \mathrm{Al}$ nearly equal to one, kaolin is considered as an ideal raw material for preparing $\mathrm{NaA}$ zeolite [8], but LTA materials prepared from natural kaoline contain easily recognized in XRD patterns quartz (strong peak at $2 \Theta=26.63^{\circ}$ ) and the SOD type zeolite (characteristic peaks at $2 \Theta=14.14^{\circ}(0.53), 24.62^{\circ}(1.00), 31.96^{\circ}(0.98)$, and $\left.35.1^{\circ}(0.78)\right)$ as impurities, not observed in XRD patterns of the samples obtained by recrystallization of SOD produced from HEU. No improvement in crystallinity like noted in [9] for high-silica zeolite A sample treated for five minutes with $12.5 \% \mathrm{NaOH}$ solution at room temperature is observed.

Developed zeolitic crystal microporous structure in synthesized samples has been confirmed also by comparatively high averaged value $\left(0.08 \mathrm{~cm}^{3} / \mathrm{g}\right.$ for SOD, and of $0.24 \mathrm{~cm}^{3} / \mathrm{g}$ for
LTA) of water adsorption capacity under static conditions at the "plateau" pressure.

FTIR. The mid infra red peak pattern shows a typical vibration pattern for the sodalite framework [10]: broad band of asymmetric stretching of $\mathrm{Si}-\mathrm{O}-\mathrm{T}$ bond observed at $900-950 \mathrm{~cm}^{-1}$ which indicates the formation of $\mathrm{Si}-\mathrm{O}-\mathrm{Al}$ bond; absorption band at $690 \mathrm{~cm}^{-1}$ due to the symmetric stretch of $\mathrm{Si}-\mathrm{O}-\mathrm{T}$; the bands at $450-475 \mathrm{~cm}^{-1}$ show the bending vibrations of $\mathrm{Si}-\mathrm{O}-\mathrm{T}[11]$.

FTIR spectra of obtained NaA zeolite shows the band at $465 \mathrm{~cm}^{-1}$ assigned according to [12] to $\mathrm{T}-\mathrm{O}$ bending vibration, band at $552 \mathrm{~cm}^{-1}$ (double ring vibration), bands between 660-800 and $1000-115 \mathrm{~cm}^{-1}$ assigned to symmetric and antisymmetric $\mathrm{T}-\mathrm{O}-\mathrm{T}$ stretching vibration, broad band in the region of $3470 \mathrm{~cm}^{-1}$ due to asymmetric stretching of $\mathrm{OH}$ group and the band at $1648 \mathrm{~cm}^{-1}$ due to bending vibration of $\mathrm{H}-\mathrm{OH}$.

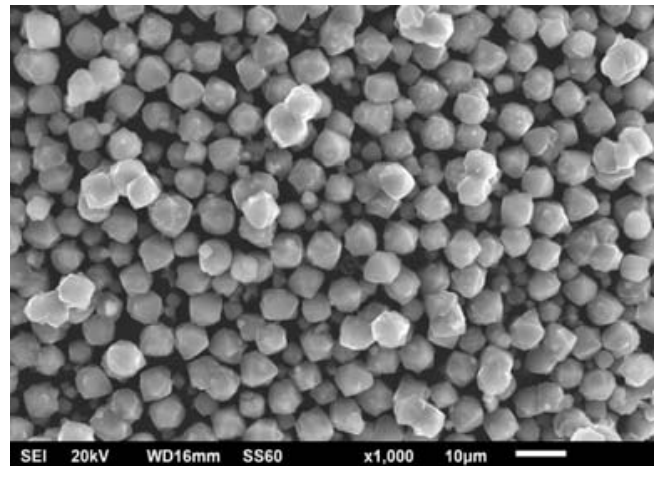

Fig. 2. SEM image of NaA microcrystals 
SEM images (Fig. 2-4) show crystalline morphology of obtained samples and testify the possibility of obtaining different crystallites depending on the crystallization rate and other parameters. Long $(>10 \mathrm{~h})$ low temperature process results in uniform crystallites with fairly narrow distribution of sizes (Fig. 2, crystallite average diameter $4 \mu \mathrm{m})$, fast $(<2 \mathrm{~h})$ process gives different fibrous aggregates (Fig. 3 , left comparatively low temperature, right - high temperature).
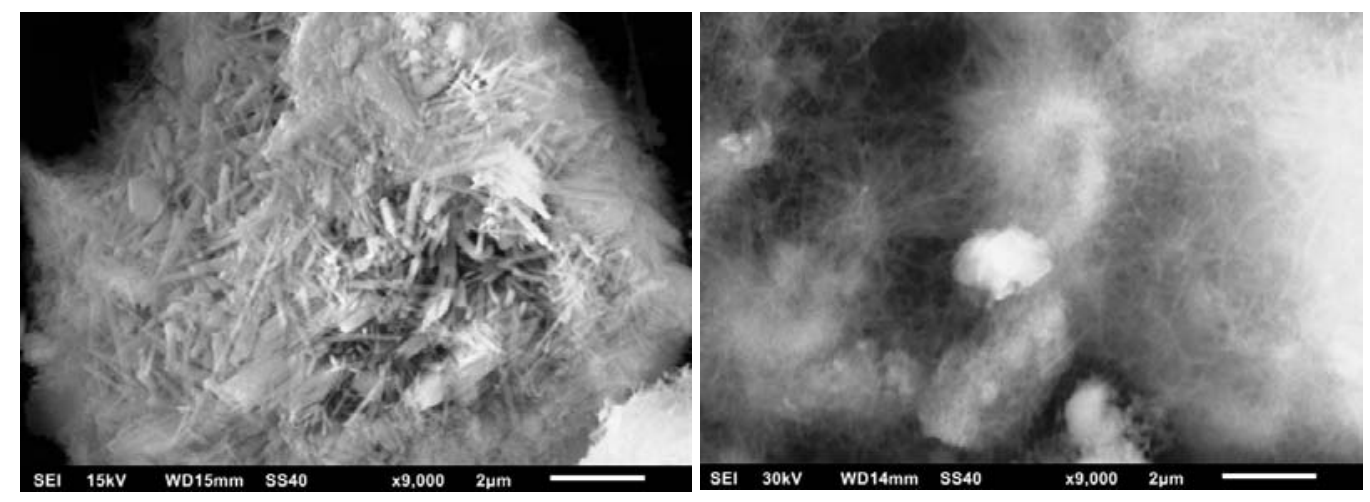

Fig. 3. SEM image of $\mathrm{NaA}$ fibrous aggregates
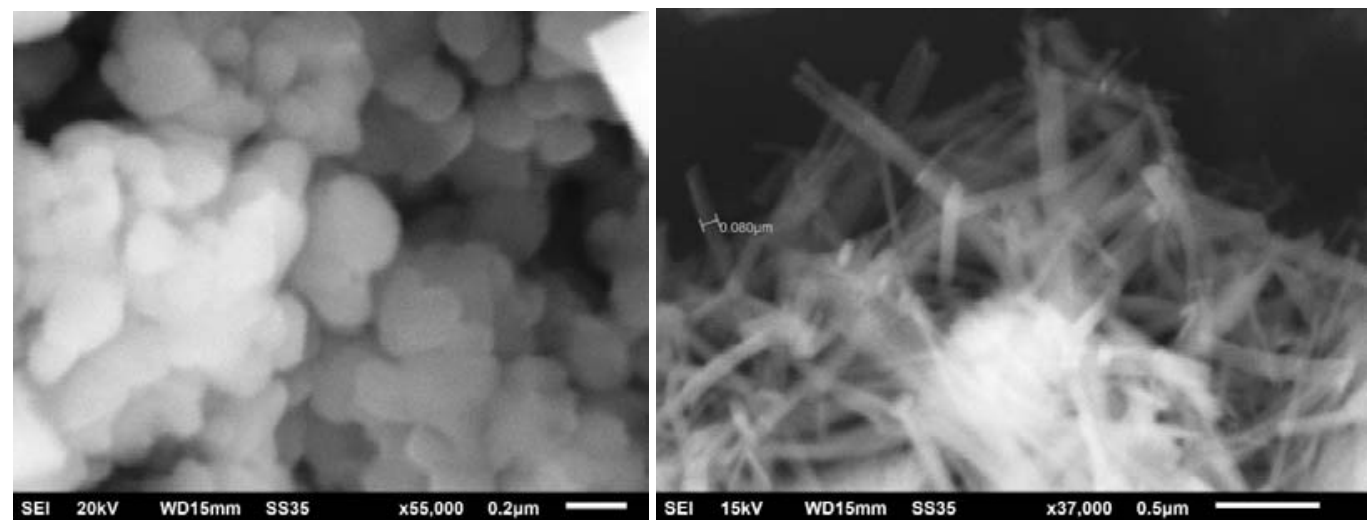

Fig. 4. SEM image of $\mathrm{NaA}$ nanoscale crystallites

Careful selection of hydrothermal crystallization conditions makes possible to prepare small crystallites (Fig. 4, left - crystallites with average diameter $0.2 \mu \mathrm{m}$ produced at low temperature, right - fibers with average diameter $0.08 \mu \mathrm{m}$ produced at comparatively high temperature) belonging to nanoscale zeolites. Obtained micrometric and narrow fibrous aggregates are a good raw material for preparation of composite and hierarchical structures [13] for various catalytic and adsorptive applications.

The proposed methods are based on the use of natural silica-alumina raw materials and inexpensive reagents $(\mathrm{HCl}, \mathrm{NaOH})$, are characterized by the relative rapidity, low energy expenditures and low Sheldon's factor E. According to the modern review [14], "template-free synthetic routes such as desilication/recrystallization will be used industrially in the future". 


\title{
Синтез цеоліту типу LTA з грузинського кліноптілоліту
}

\author{
Н.М. Долаберідзе, В.Г. Ціцішвілі, Н.А. Мірдзвелі, М.О. Ніжарадзе
}

Інститут фізичної та органічної хімії ім. П.Г. Мелікішвілі Тбіліського державного університету ім. І. Дюавахишвілі вул. Г.Політковської, 31, Тбілісі, 0186, Грузія, n_dolaberidze@yahoo.com

\begin{abstract}
Досліджено процес синтезу цеолітних матеріалів иляхом гідротермальної кристалізації природного кліноптілоліту, обробленого розчином соляної кислоти з наступним суспендуванням в розчині гідроксиду натрію. Метою дослідження була оптимізація алюмосилікатного гелю для уніфікованого одержання цеоліту NaA. Отримані продукти охарактеризовані даними скануючої електронної мікроскопії, рентгенівської діфрактометрії та ІЧ-спектроскопї. Дослідження показало, щзо висококремнисті иеоліти типу мордениту можуть бути отримані безпосередньо з зістареного гелю відповідного хімічного складу, але отримання матеріалів з порівняно високим вмістом алюмінію в одну стадію неможливо. Однак отримання матеріалів типу LTA можливо в дві стадї, маючи на увазі спершу отримання содаліту 3 $\mathrm{Si} / \mathrm{Al}=1$, а потім його перекристалізачію у цеоліт NaA. Отримані зразки характеризуються високою чистотою і ступенем кристалічності, морфологія кристалітів визначається умовами перекристалізації.
\end{abstract}

Ключові слова: цеоліт А, клиноптилоліт, содаліт, гідротермальний синтез

\section{Синтез цеолитов типа LTA из грузинского клиноптилолита}

\section{Н.М. Долаберидзе, В.Г. Цицишвили, Н.А. Мирдзвели, М.О. Нижарадзе}

Институт физической и органической химии им. П.Г. Меликишвили

Тбилисского государственного университета им. И. Дюавахишвили ул. А. Политковской, 31, Тбилиси,0186, Грузия,_n_dolaberidze@yahoo.com

Исследован процесс синтеза ичеолитных материалов путём гидротермальной кристаллизации природного клиноптилолита, обработанного раствором соляной кислоты с последующим суспендированием в растворе гидроксида натрия. Целью исследования была оптимизачия алюмосиликатного геля для унифицированного получения цееолита NaA. Полученные продукты охарактеризованы данными сканирующей электронной микроскопии, рентгеновской диффрактометрии и ИК-спектроскопии. Исследование показало, что высококремнистые цеелиты типа морденита могут быть получены непосредственно из состаренного геля соответствующего химического состава, но получение материалов со сравнительно высоким содержанием алюминия в одну стадию невозможно. Однако, получение материалов типа LTA возможно в две стадии, подразумевающих сперва получение содалита с $\mathrm{Si} / \mathrm{Al}=1$, а затем его перекристаллизацию в цеолит NaA. Полученные образцы характеризуются высокой чистотой и степенью кристалличности, морфология кристаллитов определяется условиями перекристаллизаџии.

Ключевые слова: цееолт А, клиноптилолит, содалит, гидротермальный синтез

\section{REFERENCES}

1. Choosing an adsorption system for VOC: carbon, zeolite, or polymers. EPA 456/F-99-004, May 1999.

2. Pagis C., Prates A.R.M., Farrusseng D., Bats N., Tuel A. Hollow zeolite structures: an overview of synthesis methods. Chem. Mater. 2016. 28(15): 5205.

3. Tsitsishvili V., Dolaberidze N., Alelishvili M., Tsintskaladze G., Sturua G., Chipashvili D., Nijaradze M., Khazaradze N. Adsorption and thermal properties of zeolitic rocks from newly investigated deposit plots in Georgia. Georgian Eng. News. 1998. 2(6): 61.

4. Tsitsishvili V., Dolaberidze N., Mirdzveli N., Alelishvili M., Nijaradze N., Suladze M. Chemical preparation of nano-sized zeolite materials. Study of pre-crystallization processes. Proceedings of the Georgian National Academy of Sciences. Chemical Series. 2009. 35(2): 197. 
5. Dolaberidze N.M., Tsitsishvili V.G., Mirdzveli N.A., Nijaradze M.O., Alelishvili M.V. Hydrothermal transformation of clinoptilolite to obtain fine-dispersed zeolite materials. In: Actual Problems of Adsorption Theory, Porosity and Selectivity, Materials of $2^{\text {nd }}$ All-Russian Conference with International Participation. (Moscow, 2015) P. 91.

6. Tsitsishvili V., Dolaberidze N., Mirdzveli N., Nijaradze N. MOR type synthetic zeolite material. Proceedings of the Georgian National Academy of Sciences. Chemical Series. 2016. 42(1): 7.

7. Shoumkova A., Stoyanova V. SEM-EDX and XRD characterization of zeolite NaA, synthesized from rice husk and aluminium scrap by different procedures for preparation of the initial hydrogel. J. Porous Mater. 2013. 20(1): 249.

8. Gougazeh M., Buhl J.-Ch. Synthesis and characterization of zeolite A by hydrothermal transformation of natural Jordanian kaolin. Journal of the Association of Arab Universities for Basic and Applied Sciences. 2014. 15: 35.

9. Kokotailo G.T., Fyfe C.A. Zeolite structure analysis with powder X-ray diffraction and solid-state NMR techniques. The Rigaku Journal. 1995. 12(1): 3.

10. Barthomeuf D. Framework induced basicity in zeolites. Microporous Mesoporous Mater. 2003. 66(1): 1.

11. Yao J., Zhang L., Wang H. Synthesis of nanocrystalline sodalite with organic additives. Mater. Lett. 2008. 62(24): 4028.

12. Flanigen E.M., Khatami H., Seymenski H.A. Characterization of zeolitic materials by IR spectroscopy. Adv. Chemistry Series 101. (Washington: American Chemical Society, 1971).

13. Tosheva L., Valtchev V.P. Nanozeolites: synthesis, crystallization mechanism, and applications. Chem. Mater. 2005. 17: 2494.

14. Koohsaryan E., Anbia M. Nanosized and hierarchial zeolites: a short review. Chinese J. Catalysis. 2016. 37(4): 447. 